\title{
A generalization of Nadler fixed point theorem
}

\section{FRANCESCA VETRO}

\section{ABSTRACT.}

Jleli and Samet gave a new generalization of the Banach contraction principle in the setting of Branciari metric spaces [Jleli, M. and Samet, B., A new generalization of the Banach contraction principle, J. Inequal. Appl., 2014:38 (2014)]. The purpose of this paper is to study the existence of fixed points for multivalued mappings, under a similar contractive condition, in the setting of complete metric spaces. Some examples are provided to illustrate the new theory.

\section{REFERENCES}

[1] Abbas, M., Ali, B. and Vetro, C., A Suzuki type fixed point theorem for a generalized multivalued mapping on partial Hausdorff metric spaces, Topology Appl., 160 (2013), 553-563

[2] Alghamdi, M. A., Berinde, V. and Shahzad, N., Fixed points of multivalued nonself almost contractions, J. Appl. Math., 2013, Art. ID 621614, 6 pp.

[3] Amini-Harandi, A., Fixed point theory for set-valued quasi-contraction maps in metric spaces, Appl. Math. Lett., 24 (2011), 1791-1794

[4] Aydi, H., Abbas, M. and Vetro, C., Partial Hausdorff metric and Nadler's fixed point theorem on partial metric spaces, Topology Appl., 159 (2012), 3234-3242

[5] Berinde, M. and Berinde, V., On a general class of multi-valued weakly Picard mappings, J. Math. Anal. Appl., 326 (2007), 772-782

[6] Berinde, V. and Păcurar, M., The role of the Pompeiu-Hausdorff metric in fixed point theory, Creat. Math. Inform., 22 (2013), 35-42

[7] Ćirić, L., Multi-valued nonlinear contraction mappings, Nonlinear Anal., 71 (2009), 2716-2723

[8] Chifu, C. and Petruşel, G., Existence and data dependence of fixed points and strict fixed points for contractive-type multivalued operators, Fixed Point Theory Appl, 2007, Art. ID 34248, 8 pp.

[9] Daffer, P. Z. and Kaneko, H., Fixed points of generalized contractive multi-valued mappings, J. Math. Anal. Appl., 192 (1995), 655-666

[10] Jleli, M. and Samet, B., A new generalization of the Banach contraction principle, J. Inequal. Appl., 2014:38 (2014)

[11] Kamran, T., Mizoguchi-Takahashi's type fixed point theorem, Comput. Math. Appl., 57 (2009), 507-511

[12] Mohammadi, B., Rezapour, S. and Shahzad, N., Some results on fixed points of $\alpha$ - $\psi$-Ćirić generalized multifunctions, Fixed Point Theory Appl., 2013:24 (2013)

[13] Nadler, S. B., Multivalued contraction mappings, Pac. J. Math., 30 (1969), 475-488

[14] Nieto, J. J. and Rodríguez-López, R. Contractive mapping theorems in partially ordered sets and applications to ordinary differential equations, Order, 22 (2005), 223-239

[15] Nieto, J. J. and Rodríguez-López, R., Existence and uniqueness of fixed point in partially ordered sets and applications to ordinary differential equations, Acta Math. Sin. (English Ser.), 23 (2007), 2205-2212

[16] Petruşel, A., Integral inclusions. Fixed point approaches, Comm. Math. Prace Mat., 40 (2000), 147-158

[17] Ran, A. C. M. and Reurings, M. C., A fixed point theorem in partially ordered sets and some applications to matrix equations, Proc. Amer. Math. Soc., 132 (2004), 1435-1443

[18] Rus, I. A., Petruşel, A. and Petruşel, G., Fixed Point Theory, Cluj University Press, Cluj-Napoca, 2008

[19] Sgroi, M. and Vetro, C., Multi-valued F-contractions and the solution of certain functional and integral equations, Filomat, 27 (2013), 1259-1268

[20] Vetro, C. and Vetro, F., Caristi Type Selections of Multivalued Mappings, J. Funct. Spaces, 2015, Art. ID 941856, $6 \mathrm{pp}$.

Received: 01.10.2014; In revised form: 12.03.2015; Accepted: 15.03.2015

2010 Mathematics Subject Classification. 47H10, 26E25.

Key words and phrases. Metric space, fixed point, multivalued mapping. 
[21] Zhong, C.-K., Zhu, J. and Zhao, P.-H., An extension of multi-valued contraction mappings and fixed points, Proc. Am. Math. Soc., 128 (2000), 2439-2444

UNIVERSITÀ DEGLi STUdi Di PALERMO

DIPARTIMENTO ENERGIA

INGEGNERIA DELL'INFORMAZIONE E MODELLI MATEMATICI (DEIM)

Viale DELLE SCIENZE, 90128 PALERMO, ITALY

E-mail address: francesca.vetro@unipa.it 